\title{
ANALYSIS OF THE CURRENT STATE IN INNOVATIVE RESEARCH TRAINING OF PHD STUDENTS IN UKRAINE
}

\author{
Viktoriia Meniailo \\ Zaporizhzhia National University, Zaporizhzhia, Ukraine \\ meniailo16@gmail.com
}

\begin{abstract}
The paper examines the challenges of curricular reforms aimed at updating Postgraduate study programmes of Ukrainian higher educational institutions in terms of specific innovative content and methodologies. By applying statistical methods to the data acquired from questioning first-year and second-year $\mathrm{PhD}$ students, the concept of $\mathrm{PhD}$ students' training (comprising formal, content-based and methodological aspects) has been reconstructed from the point of view of its key beneficiaries. The research results show that the majority of postgraduate students consider research and innovation activities as an important part of their future professional activity; the level of innovative research training in Postgraduate Education is rated as higher than average, while their own level is viewed as average. The paper outlines main forms of research and innovation activities in which the students participated as well as difficulties which they encountered. As a result of the quantitative analysis, the author presents the rating of the most important modules, which should be included in the curriculum of Postgraduate studies (Foreign Language for Specific Purposes, Methodology of Scientific Research, Methods of Mathematical Statistics, Academic Writing and Academic Integrity, Critical Thinking Basics, Innovation basics, Intellectual Property and Technology Transfer, Project Activity Basics). The paper also outlines the most effective, in students' opinion, forms and methods of innovative research training in the process of Postgraduate Studies, including preparation of scientific publications to be submitted to international journals; workshop conducting, organisation of thematic meetings with successful scientists and entrepreneurs; on-the-job training in leading research centres; participation in interdisciplinary discussion workshops; participation in youth contests of innovative ideas and projects; participation in scientific research conferences and workshops; realisation of scientific research and social projects. The obtained results can be used for the development of educational and scientific programmes for the third level of higher education and construction of a model for innovative research training of the future $\mathrm{PhD}$ candidates.
\end{abstract}

Keywords: PhD programme; innovative research activities; postgraduate student; innovative research training.

\section{Introduction}

Following the Order of the Cabinet of Ministers of Ukraine of March 23, 2016, No. 261, a curricular reform aimed at designing innovative Postgraduate study programmes has been launched by Ukrainian higher educational institutions. The updated curricula should provide a $\mathrm{PhD}$ applicant with "theoretical knowledge, abilities, skills and other competences sufficient to produce new ideas, solve complex problems in the field of professional and/or research and innovation activities..." (The Cabinet of Ministers of Ukraine, 2016). Thus, institutions of higher education faced the problem of raising the efficiency of their postgraduate study programmes by making their content more relevant to future $\mathrm{PhD}$ candidates' professional needs.

Due to the fact that Postgraduate studies have become a part of Ukrainian higher education system only beginning from 2014 (Sysoieva, Mospan, 2015), the number of research papers focused upon the challenges of curricular reform in the field (Talanova, 2010; Pozhyvilova, 2006; Rehejlo, 2014; Sydorchuk, 2017) is by far quite limited.

Taking into account the fact that an educational component of a new Ukrainian model of postgraduate studies definitely lacks definability in terms of implementation, it seems rational to analyse foreign experience of postgraduate students training for relevant educational and scientific programmes (in this aspect, the work by Sysoieva \& Rehejlo (2016) is of a considerable interest, as it reveals content, forms and methods of PhD students' training in the USA, as well as the study of students' opinion on the content of their training. Thus, this paper is focused on the research of the postgraduate students' point of view on the modern processes of preparing $\mathrm{PhD}$ in Ukraine, as noted by Baldwin (2016): "our interaction with our learners...is a fundamental aspect of their learning and achievement" (p. 91).

The aim of the paper is to analyse the current state of innovative research training of $\mathrm{PhD}$ students and define the content, forms and methods of this training from the point of view of its beneficiaries.

The research objectives are as follows:

- to explain the essence of the concept of "innovative research activities of $\mathrm{PhD}$ students" as understood by $\mathrm{PhD}$ students themselves;

- to define the place that innovative research activities occupy in professional activities of the future $\mathrm{PhD}$ candidates, from their own point of view;

- to study the results of students' assessment of the course in Research and Innovation Activities as a part of Postgraduate Studies programme; 
- to study the results of students' self-assessment defining their personal proficiency in research and innovation activities;

- to establish the forms and difficulties of innovative research activities in which postgraduate students personally took part;

- to determine the content, forms and methods of innovative research preparation of PhD students and compare the acquired results with the results of similar studies.

\section{Methods}

To solve the tasks, a questionnaire "Training in Research and Innovation Activities for Doctor of Philosophy" was developed for graduate students of higher education institutions. The questionnaire was conducted online by filling out the specified questionnaire in Google-Forms. The processing of the obtained results was carried out by means of the software IBM. SPSS. Statistics.v.20.

$118 \mathrm{PhD}$ students of the first and second years of studies from 17 higher education institutions of Ukraine, in particular Zaporizhzhia National University, Oles Honchar Dnipro National University, Classic Private University, Taras Shevchenko Kyiv National University, Mykolaiv Sukhomlynskyi National University, Kyiv-Mohyla Academy National University, Ivan Franko National University of Lviv and others, took part in the survey.

\section{Results}

\section{General information about postgraduate students}

The first part of the questionnaire included questions related to the characteristics of postgraduate students. It was found out that among the respondents there were 73 postgraduate students of the first year of studies and 45 of the second year of studies. A half of the respondents $(\mathrm{N}=59)$ do not have an experience in scientific, scientific and pedagogical work; 37 postgraduate students have a three-year experience; 20 applicants of the third level of education have an experience from 3 to 10 years, and only two postgraduate students have more than 10 years of research and academic experience. The vast majority of prospective $\mathrm{PhDs}(\mathrm{N}=84)$ are preparing their thesis in the field of social sciences and humanities, 24 postgraduate students are working in the field of natural and mathematical sciences and 10 postgraduates are carrying out their research in technical and engineering sciences. students.

The essence, place and role of innovative research in the professional activity sphere of the PhD

The second part of the survey included issues related to the nature, place and role of research activities in the professional development of the $\mathrm{PhD}$ students. The first question in this block was open, as postgraduates were offered to independently define the concept of "innovative research activities of the doctor of philosophy". The content analysis of the provided answers showed that $36(30.51 \%)$ respondents identify innovative research activities as scientific results that represent new knowledge; 19 (16.10\%) applicants see it as a scientific innovation, which results in obtaining new knowledge and implementing it in an innovative way; $41(34.75 \%)$ postgraduate students consider innovative research activities as a means of obtaining new knowledge suitable for practical use. At the same time, only two respondents commented on the commercial nature of this activity. $22(18.64 \%)$ of the applicants or almost a fifth of them failed to disclose the essence of the proposed concept or didn't give the answer to this question at all. The given results testify that postgraduate students don't have a clear idea about the essence and structure of this type of activity.

Nevertheless, the overwhelming majority of respondents (91.53\%) consider innovative research activities as an important part of the professional activity of a PhD candidate. $61.02 \%$ of respondents totally agree with this statement; $30.51 \%$ of respondents are more likely to agree with this statement than not to; $8,47 \%$ fairly disagree with it; and there no respondents who were completely against it.

As for the rate of its significance for the future researcher or academic staff member, the specific scientific awareness (according to the field of knowledge and speciality) turned out to be the most important competence for postgraduate students. 60 respondents put it in the first place and 31 in the second place. Research and innovation competence goes next, with 27 applicants ranking it as the most important one and 44 applicants as the second most important); psychological and pedagogical competence occupies the third place ( 73 postgraduate students determined it to the third and fourth places); 56 applicants of a scientific degree ranked organisational and managerial competence at the fourth place. The average value of the ranks of these competencies was accordingly: 1.79, 2.29, 2.66 and 3.25.

Thus, innovative research competence occupies the second place after a specific scientific awareness among the professional competences of a scientist. 
$83.90 \%$ of respondents agree that in the process of postgraduate studying it is necessary to prepare future specialists for research and innovation activities. Only $2.54 \%$ of respondents say that it is unnecessary and $13.56 \%$ are unspecified postgraduates.

The level of innovative research training of $P h D$ students and self-assessment of experience of innovative research activities

These questions represent the third part of the questionnaire. Most scholars $(\mathrm{N}=87)$ consider the level of training in innovative research activities provided by Postgraduate Study programme to be rather high (25.42\% admitted it as a very high and $48.31 \%$ - higher than average); 27 applicants (22.9\%) assessed it as average; 4 postgraduate students (3.4\% of respondents) rated it below average. The average value of this indicator on the 5-point scale is 3.96 (Figure1).

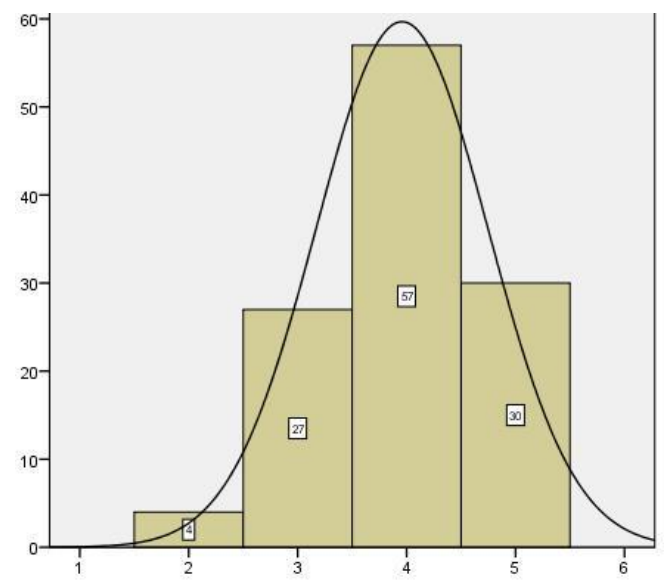

Figure 1. Distribution of PhD students' answers to the question of the quality of training in innovative research activities provided within Postgraduate Studies programme (1 - very low, 2 - below average, 3 - average, 4 - above average, 5 - very high) (in frequencies)

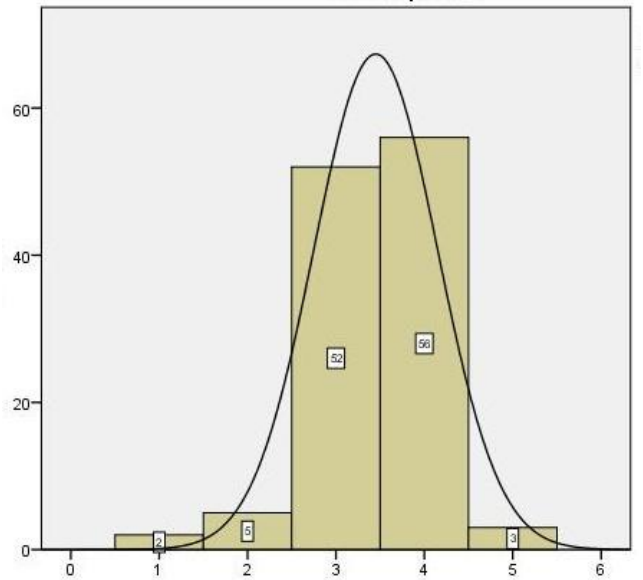

Figure 2. Distribution of postgraduate students' answers to the questions about their own level of preparation for innovative research activities (in frequencies)

It should be noted that the first-year PhD students assessed rather the expected level of preparation for innovative research activities during Postgraduate Studies, while postgraduate students of the second year of studies already had some experience in such training. The distribution of postgraduate students' answers over the years of study showed that $\mathrm{PhD}$ students of the first year consider the level of Postgraduate Studies slightly higher (in average - 4.01) than postgraduate students of the second year of studies (in average - 3.87).

Postgraduates consider their own level of readiness for research and innovation to be not so high. Only half of them (50\%) recognised it as higher than above average $(47.46 \%)$ and very high $(2.54 \%) ; 44.07 \%$ rated it as average; $4.24 \%$ - below average and $1.69 \%$ - as very low. The average value of this indicator on the 5-point scale is 3.45 (Figure 2).

The distribution of responses by postgraduate students of the first and second years of studies showed that postgraduate students of the second year slightly better assess their level of preparation for innovative research activities (average value 3.53) than postgraduate students of the first year of studying (average - 3.40).

$46.58 \%$ of the first-year $\mathrm{PhD}$ students determined their level of preparation for innovative research activities in Postgraduate Studies as very high and above average, while among the second-year postgraduate students this kind of answer comprises $55.55 \% .46 .58 \%$ of the first year postgraduate students and $40.00 \%$ of the second year postgraduate students assessed their readiness as an average. More clearly, the difference between the levels of postgraduate training for different years of education is reflected on Fig. 2 by the median: for the first year of training it equals 3.00; for the second it is 4.00 .

The results of PhD students' answers to the questions about the forms of innovative research activities they took a personal part in, were distributed as follows (Figure 3). More than $80 \%$ of postgraduate students participated in conferences and round tables presenting their research results; $50 \%$ of respondents participated in research contests for students and young scientists; half of the respondents prepared papers for publication in international scientific journals, while this indicator was significantly higher in postgraduate students of the second year of study $(66.6 \%)$ than in the first year of study $(42.5 \%)$; one third of postgraduate students have experience in communicating with foreign colleagues, and for the first-year $\mathrm{PhD}$ students this figure was even slightly higher (36.9\%) than for postgraduate students of the second year of studies (31.1\%). 
Participation in foreign business trips and internship was taken by $24.4 \%$ of second-year $\mathrm{PhD}$ students and $21.9 \%$ of the first-year $\mathrm{PhD}$ students. The significant difference between the postgraduate students of the first and second years of studies was in the number of those who participated in preparation of grant applications and in contests of research projects. Among second-year PhD students, 35.6\% and 24.4\% participated in these forms of activity, whereas among postgraduate students of the first year there were only $20.5 \%$ and $17.8 \%$ respectively. A slightly smaller number of postgraduate students took part in the implementation of such projects: $20.0 \%$ second-year $\mathrm{PhD}$ students and $15.1 \%$ of the first-year $\mathrm{PhD}$ students. $16.1 \%$ of all postgraduate students were involved in the development of new technologies and methods, and $10.2 \%$ of the second year students and $4.1 \%$ of the first year participated in preparation of applications for the protection of intellectual property objects. None of the respondents took part in the development and/or production of innovative products.

The given statistical data testify the relatively low level of postgraduate students' preparation for innovative research activities. In this regard, we will further analyse the answers of respondents to the question: "What difficulties did you encounter in performing these types of work?" (Figure 4). Among the main difficulties encountered by future specialists, at the first place there was the lack of experience in writing projects, processing applications, signing contracts, as indicated by $52.5 \%$ of the respondents. At the same time, the lack of such experience was noted by $55.5 \%$ of the second-year $\mathrm{PhD}$ students and $50.7 \%$ of the first-year $\mathrm{PhD}$ students. 51.7\% of the respondents noted lack of time (among the second-year $\mathrm{PhD}$ students $53.3 \%$ pointed at such difficulties, while among the first-year PhD students $-50.7 \%$ ). $42.2 \%$ of the second-year $\mathrm{PhD}$ students and $46.6 \%$ of the first-year $\mathrm{PhD}$ students marked the insufficient level of proficiency in the foreign language. $33.1 \%$ of respondents indicate lack of information. $31.1 \%$ of the secondyear $\mathrm{PhD}$ students and $28.8 \%$ of the first-year $\mathrm{PhD}$ students feel uncertain about their abilities. About $24.4 \%$ of the second-year PhD students and only $16.4 \%$ of the first year postgraduate students stated among the difficulties the lack of knowledge and skills. The last two positions indicate a more critical approach to assessing their capabilities by the second-year PhD students. It was interesting to find out that only $2 \mathrm{PhD}$ students out of 118, among the list of difficulties that they encountered indicated the lack of funding.

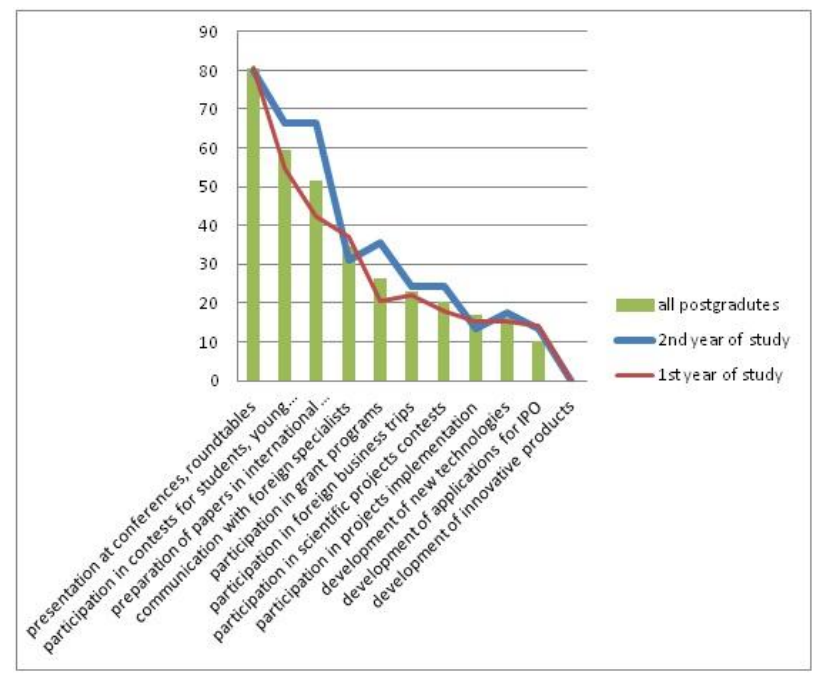

Figure 3. Distribution of postgraduate students' answers to the types of activities they were involved (in percentage)

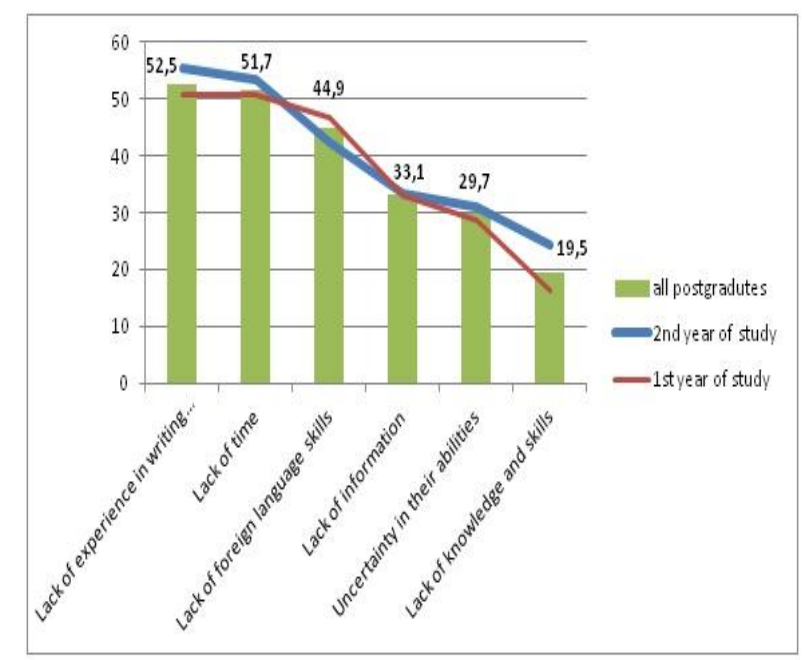

Figure 4. Distribution of PhD students' answers regarding the difficulties they encountered during the performance of work (in percentages)

Contents, forms and methods of innovative research preparation of PhD students

And, finally, the fourth part of the questionnaire was devoted to the content, forms and methods of innovative research training of $\mathrm{PhD}$ students. To define the content of innovative research training, postgraduates were asked to answer the question: "What modules would you recommend to include in the postgraduates curriculum?" as well as to offer their own modules to the educational process.

The rating of the first ten selected modules by students is as follows:

1. Foreign Language for Specific Purposes.

2. Methodology of Scientific Research.

3. Academic Writing and Academic Integrity.

4. Critical Thinking Basics. 
5. Innovation Basics.

6. Intellectual Property and Technology Transfer.

7. Project Activity Basics.

8. Academic Mobility and Participation in International Grants Programmes.

9. Information and Communication Technologies in Scientific Research.

10. Working with Library Resources and scientific citation indexing services.

In addition to the identified modules, applicants were offered training modules, which relate, first of all, to the mathematical methods of scientific research, as well as modern communication basics, rhetoric, time management, etc.

Regarding the efficiency of forms and methods of PhD students' innovative research training, their first ten responses are as follows:

1. Publishing in international peer-reviewed journals.

2. Participation in workshops, thematic meetings with successful scholars and entrepreneurs.

3. Internship at the leading Ukrainian research centres.

4. Participation in interdisciplinary discussion workshops, including those conducted in English.

5. Participation in youth contests of innovative ideas and projects.

6. Participation in scientific conferences and workshops.

7. Participation in research, educational, social and other projects.

8. Participation in programmes of international academic mobility.

9. Participation in project groups on the writing grant applications.

10. Preparation of applications for the acquisition of intellectual property rights.

In addition to these forms and methods of preparation, the postgraduate students offered the following: meetings with potential investors, working out foreign literature, nationwide Internet network for PhDs, preparing and conducting activities aimed at popularising science among youth, etc.

\section{Discussion}

Taking into account the results of conducted research, it can be stated that the educational and scientific programme of $\mathrm{PhD}$ preparation should necessarily include such modules as: Methodology of Scientific Research; Mathematical Methods in Scientific Research; Innovative and Project Activity; Foreign Language for Specific Purposes, as well as forms that will provide the postgraduate students with the skills of academic writing, critical thinking, modern communication, rhetoric, time management skills, etc. These forms include: preparation of scientific publications in international editions, workshops, thematic meetings with renowned scholars and entrepreneurs, interdisciplinary discussion workshops, participation in youth contests of innovative ideas and projects, participation in conferences and workshops, participation in the preparation and implementation of research, educational, social and other projects. The efficiency of such organisational forms and methods of learning activities as round tables, group discussions, conferences, teamwork is also confirmed by Fiialka, Onkovych, \& Baliun (2017) who point out that "these methods allow students to develop flexibility of thought, adaptation to real work situations, initiative, autonomy in decision-making and at the same time the ability to work in a team, creative approach to problem-solving" (p. 57), that is, they enable them to master the key competencies that are urgently needed by a modern specialist in higher education.

The results obtained in the process of empirical research confirm the theoretical conclusions made by Sysoieva, Rehejlo (2016), on the basis of their analysis of PhD training in the USA:

"when training a $\mathrm{PhD}$ candidate, considerable attention should be paid to mastering the methods of scientific research, [...] organisational aspects of experimental work and verification of its results, [...] methods of mathematical statistics. It is necessary to introduce such forms of training that would stimulate the development of communicative abilities, critical thinking, teamwork, creative thinking and the like (regular conferences, roundtable discussions for PhDs, problem-focused workgroups).” (p. 91)

The practical significance of the results is that they can be used to develop educational and scientific programmes for the third level of higher education in Ukraine and increase the effectiveness of innovative research training of philosophy doctors.

\section{Conclusions}

By applying statistical methods to the data acquired from questioning first-year and second-year $\mathrm{PhD}$ students, we have revealed the present-day state of curricular reform in the field of Postgraduate studies within the framework of sociological research, outlined the current state of innovative research training of 
future $\mathrm{PhDs}$ and defined the content, forms and methods of this training in Ukraine. It is shown that the majority of postgraduate students consider innovative research activities as an important part of the professional activity of $\mathrm{PhD}$ candidate; they rate the level of innovative research training in Postgraduate Studies as higher than average; their own level is estimated as average. The results of the questionnaire compiled the rating of the most important modules, which should be included in the curricula of postgraduate students as well as the most effective, in their opinion, forms and methods of innovative research training. The results obtained in this paper will be used in further research on the development of a model of innovative research training for $\mathrm{PhD}$ students.

\section{Acknowledgements}

The paper was prepared within the framework of Erasmus+ Project: Jean Monnet actions-587321-EPP-1-20171-UA-EPPJMO-MODULE “European Project Culture” (Zaporizhzhia National University, 2017-2020).

\section{References:}

Baldwin, L. (2016). Editorial. Active Learning in Higher Education, 17, 91-97. https://doi.org/10.1177/1469787416647537

Cabinet of Ministers of Ukraine (2016). "Resolution of the Cabinet of Ministers of Ukraine no. 261 "On Approval of the Procedure for Preparing Doctors of Philosophy and Doctors of Sciences in Higher Educational Institutions (Scientific Institutions)". Retrieved May 20, 2018, from http://zakon3.rada.gov.ua/laws/show/261-2016-\%D0\%BF

Fiialka, S., Onkovych, H., Baliun, O. (2017). The use of modern teaching methods in editor education in Ukraine. Advanced Education, 7, 57-63. https://doi.org/10.20535/2410-8286.88019

Pozhyvilova, O. (2006). Rozvytok systemy pidhotovky naukovykh $i$ naukovo-pedahohichnykh kadriv vyschoi kvalifikatsii $v$ ievropejs'komu rehioni ta Ukraini (1990-2005 rr.) [Development of the training system for scientific and scientificpedagogical staff of higher qualification in the European region and Ukraine (1990-2005). Extanded abstract of doctoral dissernation), Kyiv, Ukraine: Instytut vyschoi osvity APN Ukrainy.

Rehejlo, I. (2014). Pidhotovka naukovykh i naukovo-pedahohichnykh kadriv vyschoi kvalifikatsii v Ukraini u XX - pochatku XXI stolittia [Preparation of scientific and scientific-pedagogical staff of higher qualification in Ukraine in XX - beginning of XXI century]. Kyiv, Ukraine: Osvita Ukrainy.

Sydorchuk, N. (2017). Shliakhy onovlennia pidhotovky doktoriv filosofii na zasadakh kompetentnisnoi paradyhmy [Ways to renew the training of $\mathrm{PhD}$ on the basis of a competent paradigm]. Visnyk Zhytomyrs'koho derzhavnoho universytetu imeni Ivana Franka, 2 (88), 249-253.

Sysoieva, S. \& Mospan, N. (2015). New law on higher education in Ukraine: Innovations and risks. Didactica Slovenica - Pedagoska Obzorja, 30 (3-4), 166-174.

Sysoieva, S. \& Rehejlo, I. (2016). Zmist pidhotovky doktoriv filosofii u haluzi osvity v universytetakh SShA [Contents of Doctorate in PhD in Education training in the US Universities]. Pedahohichnyj protses: teoriia i praktyka (seriia: pedahohika), 2(53), 86-93.

Talanova, Zh. (2010). Doktors'ka pidhotovka u sviti ta Ukraini [Doctoral training in the world and Ukraine]. Kyiv, Ukraine: Milenium. 